\title{
Social Aspects of CSCL Environments: A Research Framework
}

Citation for published version (APA):

Kreijns, K., Kirschner, P. A., \& Vermeulen, M. (2013). Social Aspects of CSCL Environments: A Research Framework. Educational Psychologist, 48(4), 229-242. https://doi.org/10.1080/00461520.2012.750225

DOI:

$10.1080 / 00461520.2012 .750225$

Document status and date:

Published: 01/10/2013

Document Version:

Version created as part of publication process; publisher's layout; not normally made publicly available

\section{Document license:}

CC BY

Please check the document version of this publication:

- A submitted manuscript is the version of the article upon submission and before peer-review. There can be important differences between the submitted version and the official published version of record. People interested in the research are advised to contact the author for the final version of the publication, or visit the DOI to the publisher's website.

- The final author version and the galley proof are versions of the publication after peer review.

- The final published version features the final layout of the paper including the volume, issue and page numbers.

Link to publication

\section{General rights}

Copyright and moral rights for the publications made accessible in the public portal are retained by the authors and/or other copyright owners and it is a condition of accessing publications that users recognise and abide by the legal requirements associated with these rights.

- Users may download and print one copy of any publication from the public portal for the purpose of private study or research.

- You may not further distribute the material or use it for any profit-making activity or commercial gain

- You may freely distribute the URL identifying the publication in the public portal.

If the publication is distributed under the terms of Article 25fa of the Dutch Copyright Act, indicated by the "Taverne" license above, please follow below link for the End User Agreement:

https://www.ou.nl/taverne-agreement

Take down policy

If you believe that this document breaches copyright please contact us at:

pure-support@ou.nl

providing details and we will investigate your claim.

Downloaded from https://research.ou.nl/ on date: 26 Apr. 2023 
This article was downloaded by: [Open Universiteit]

On: 02 May 2013, At: 00:53

Publisher: Routledge

Informa Ltd Registered in England and Wales Registered Number: 1072954 Registered office: Mortimer House, 37-41 Mortimer Street, London W1T 3J H, UK

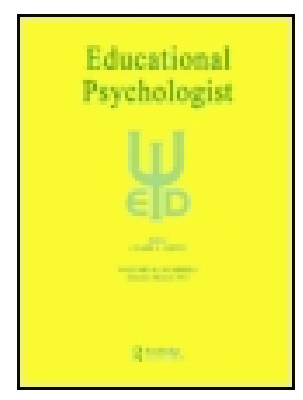

\title{
Educational Psychologist
}

Publication details, including instructions for authors and subscription information: http:// www. tandfonline.com/loi/ hedp20

\section{Social Aspects of CSCL Environments: A Research Framework}

\author{
Karel Kreijns ${ }^{a}$, Paul A. Kirschner ${ }^{b} \&$ Marjan Vermeulen ${ }^{c d}$ \\ ${ }^{a}$ Scientific Centre for Teacher Research, Open University of The Netherlands \\ ${ }^{\mathrm{b}}$ Centre for Learning Sciences and Technologies, Open University of The Netherlands \\ ${ }^{c}$ KPC Holding, The Netherlands \\ ${ }^{\mathrm{d}}$ Teacher University, Open University of The Netherlands \\ Published online: 30 Apr 2013.
}

To cite this article: Karel Kreijns, Paul A. Kirschner \& Marjan Vermeulen (2013): Social Aspects of CSCL Environments: A Research Framework, Educational Psychologist, DOI: 10.1080/ 00461520.2012.750225

To link to this article: http:// dx. doi.org/ 10.1080/00461520.2012.750225

\section{PLEASE SCROLL DOWN FOR ARTICLE}

Full terms and conditions of use: http://www.tandfonline.com/page/terms-and-conditions

This article may be used for research, teaching, and private study purposes. Any substantial or systematic reproduction, redistribution, reselling, loan, sub-licensing, systematic supply, or distribution in any form to anyone is expressly forbidden.

The publisher does not give any warranty express or implied or make any representation that the contents will be complete or accurate or up to date. The accuracy of any instructions, formulae, and drug doses should be independently verified with primary sources. The publisher shall not be liable for any loss, actions, claims, proceedings, demand, or costs or damages whatsoever or howsoever caused arising directly or indirectly in connection with or arising out of the use of this material. 


\title{
Social Aspects of CSCL Environments: A Research Framework
}

\author{
Karel Kreijns \\ Scientific Centre for Teacher Research \\ Open University of The Netherlands \\ Paul A. Kirschner \\ Centre for Learning Sciences and Technologies \\ Open University of The Netherlands \\ Marjan Vermeulen \\ KPC Holding \\ The Netherlands \\ Teacher University \\ Open University of The Netherlands
}

\begin{abstract}
Although there are research findings supporting the positive effects of computer-supported collaborative learning (CSCL), problems have been reported regarding the learning process itself, group formation, and group dynamics. These problems can be traced back to impeded social interaction between group members. Social interaction is necessary (a) for group members to learn from each other in a CSCL environment and (b) for socioemotional processes to help create a social space where trust, sense of community, and strong interpersonal relationships exist. This article introduces a theoretical framework consisting of three core elements: sociability, social space, and social presence, along with their relationships with group members' mental models, social affordances and learning outcomes. It postulates that the three core elements influence the social interaction needed for both learning and the emergence of a social space. This framework serves as a basis for a research agenda for systematic social CSCL research.
\end{abstract}

Web 2.0 technology has given computer-supported collaborative learning (CSCL) environments an enormous technology push forward. Web 2.0 is a catch-all name for technology that provides web-based applications with a high degree of interactivity (i.e., user interaction) as opposed to only allowing for passive viewing of static content. An often-used synonym is social software because these applications allow the interactive qualities of the technology to connect users with each other so that they can communicate, collaborate, and share. Present-day CSCL environments use social software applications such as Skype and Twitter for communication, weblogs and wikis for collaboration, and Dropbox or other cloud services for information sharing. Educators and

Correspondence should be addressed to Karel Kreijns, Scientific Centre for Teacher Research (LOOK), Open University of The Netherlands, Valkenburgerweg 177, 6419 AT Heerlen, The Netherlands. E-mail: karel.kreijns@ou.nl teachers are becoming convinced that these advanced CSCL environments are a promising new generation of tools for online education, supporting a learner-centered perspective on collaborative learning (Voogt \& Pelgrum, 2005). However, as advanced as these environments may be, research has shown that there are two severe problems that prevent them from achieving their promise and potential (see also Kreijns, Kirschner, \& Jochems, 2003).

\section{Problem 1}

Following Vygotsky (1978), scholars agree that the key element in collaborative learning is the social interaction among learning group members because social interaction is particularly important for reaching shared understanding and the construction of knowledge through social negotiation of views and meanings (Hiltz, 1994). In particular, Hiltz (1994) concluded that "this social process of developing shared 
understanding through interaction is the 'natural' way for people to learn" (p. 22). Thus, social interaction is an essential condition for collaborative learning (Johnson, Johnson, \& Stanne, 1985). Web 2.0 technologies seem to be a promising vehicle to promote such interactions within CSCL environments.

However, regardless of a CSCL environment's use of Web 2.0 as a tool for communication, collaboration, and sharing, researchers and teachers both find that the expected social interaction often does not occur. In a study of the use of course newsgroups as a CSCL environment, Bagherian and Thorngate (2000) concluded that

an overwhelming majority of students never posted messages on newsgroups, nor did their instructors. In addition, a large majority of students rarely read what others had posted. Students were more likely to post messages when graded for doing so and when encouraged by the active involvement of their instructors, though the quality of the resulting discussions remained questionable. The few instructors who were enthusiastic about the educational potential of course newsgroups worried about the large amounts of time spent on reading, answering, and grading students' postings and about the lack of career rewards for these activities.

Muilenburg and Berge (2005) found that a basic lack of social interaction was the most severe barrier to collaboration perceived by online groups. Simply enabling social interaction, therefore, is not enough; it must be stimulated. One way to do this is to apply a specific CSCL pedagogy, that is, a pedagogy specific to the CSCL context. Fischer, Kollar, Stegmann, and Wecker (2013) posit scripting as just such a pedagogy.

\section{Problem 2}

Although the availability of a CSCL pedagogy that stimulates social interaction is necessary for promoting learning, it may not be sufficient. In CSCL the socioemotional processes that shape the group's development (Bales, 1999; Forsyth, 2009; Tuckman \& Jensen, 1977) are an issue that requires the special attention of CSCL researchers. Only when the group development results in a social space where trust, sense of community, and strong interpersonal relationships exist can CSCL pedagogy be successfully applied. Consequently, it must be ensured that facilitative socioemotional processes found in traditional face-to-face collaborative learning also occur in CSCL environments. To that end, the social interaction should be directed not only toward cognitive processes but also toward socioemotional processes that underlie these cognitive processes; hence, social interaction has both a cognitive dimension and a socioemotional dimension (Bales, 1999).

Cognitive processes refer to the acquisition of knowledge and skills through the CSCL pedagogy; social-emotional processes refer to the group development (i.e., the group forming and group dynamics). Unfortunately, most of the functionality in CSCL environments is designed and implemented to facilitate formal cognitive processes necessary for learning, whereas the informal, social-emotional processes are not typically the focus of instructional design. This is because researchers and educators tend to limit interaction possibilities to the cognitive dimension (i.e., social interaction only serves learning) and the task context (i.e., the social interaction only take place in strictly defined task settings). Consequently, most learning environments, including CSCL, are developed consistent with this view. There are, however, CSCL scholars who argue that attention also should be paid to the socio-emotional dimension of social interaction. For example, Wegerif (1998) emphasized the point that "many evaluations of asynchronous learning networks understandably focus upon the educational [i.e., the cognitive] dimension, either learning outcomes or the educational quality of interactions, overlooking the social [i.e., the socio-emotional] dimension which underlie this" (p. 34). Social interaction in the socio-emotional dimension is typically fostered in nontask contexts, thus outside of the defined learning settings, and it usually tends to be more casual. Indeed, Northrup (2001) stated that through casual interaction

learning more about peers and connecting them in non-task specific conversation is more likely to occur. Although social interaction may have very little to do with a course, it is still valued as the primary vehicle for student communications in a Web-based learning environment. (p. 32)

Task contexts are confined to the learning setting; in current, traditional CSCL environments this learning setting is salient through elements like discussion boards/newsgroups (for discussing topics related to the group task), formal e-mail communication, repositories for course documents and the group products, and course announcements (e.g., when are the deadlines). In real life, it would be the classroom. Nontask contexts are everything that is outside the learning setting; in CSCL environments this could be the "getting-to-know" area, and in real life it would be the school's hallway, the canteen, the places outside the building, and so on.

Figure 1 depicts the cognitive and the socioemotional dimensions of social interaction for task and nontask contexts. Traditional CSCL environments only focus on Quadrant I, but even in the tightly defined learning settings, it still is possible to have social interaction that serves the socioemotional dimension (Quadrant II), although this type of social interaction is usually limited. Thus, if traditional CSCL environments are used then the social interaction found in the CSCL group will likely to cover Area 1 in Quadrants I and II. Future CSCL environments, however, should also focus on Quadrant IV. Even in nontask settings it is still possible to have social interactions that serve the cognitive dimension (Quadrant III). The social interaction found in CSCL groups 


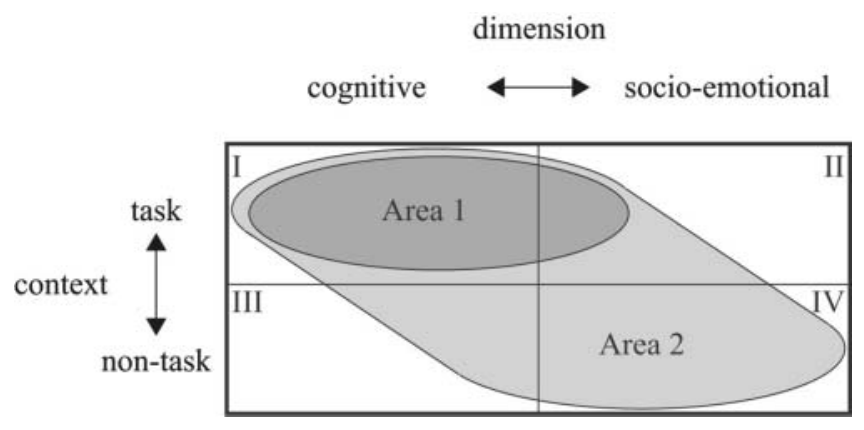

FIGURE 1 Dimensions and contexts of social interaction.

that uses those future CSCL environments will, therefore, likely cover Area 2 in all quadrants.

Note that some researchers call social interaction in the cognitive dimension on-task, educational, instructional, or pedagogical interaction and refer to social interaction in the social dimension as nontask, off-task, social, or nonpedagogical interaction (e.g., Abedin, Daneshgar, \& D'Ambra, 2012; Gilbert \& Moore, 1998). By using these terms, these researchers do not really distinguish between dimensions and contexts of social interaction but see the interactions as concentrated either in Quadrant I or in Quadrant IV. They can, therefore, interchange terms that are associated with the cognitive dimension (e.g., "pedagogical") with terms that are associated with the task context (e.g., "on-task"). Similarly, they can interchange terms that are associated with the socioemotional dimension (e.g., "nonpedagogical") with terms that are associated with nontask contexts (e.g., "off-task"). We hope that Figure 1 helps to provide some clarity to the confusing terminology that has been used in the literature.

To remedy the lack of a socioemotional dimension in traditional CSCL environments, Donath (1997) suggested that future CSCL environments should not neglect Quadrant IV and advocated the design of online social environments. To foster the development of vibrant online communities, an environment must provide the means to communicate social cues and information. This means that users of an environment must be able to perceive social patterns of activity and affiliation, and the community must be able to develop a fluid and subtle cultural vocabulary. In other words, what is needed are sociable CSCL environments: CSCL environments with both cognitive and social functionalities. Sproull and Faraj (1997) stressed this need:

People on the net are not only solitary information processors but also social beings. They are not only looking for information; they are also looking for affiliation, support and affirmation. Thinking of people on the net as social actors evokes a metaphor of a gathering. Behaviors appropriate at the gathering include chatting, discussing, arguing, and confiding. People go to a gathering to find others with common interests and talk with or listen to them. When they find a gathering they like, they return to it again and again. (p. 38)

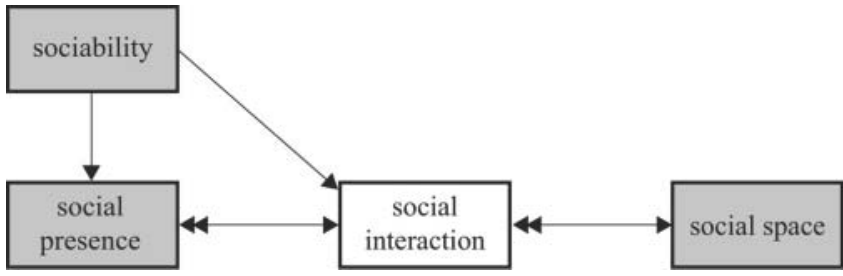

FIGURE 2 The three constitutive elements of our theoretical framework of our research on social interaction in computersupported collaborative learning (CSCL) environments: sociability, social space, and social presence.

\section{Structure of the Article}

This article continues with an elaboration of sociability as an attribute of the CSCL environment. It is defined as the extent to which a CSCL environment can facilitate the emergence of a sound social space through socioemotional interaction. A sound social space is characterized by strong interpersonal relationships, trust, and a sense of cohesion. These qualities form the conditions for creating an optimal social context for collaborative learning. The extent to which the social space becomes sound depends on the social presence of the participants; the degree to which people experience each other as "real" people in the communication. In this article, we explain that this degree of "realness" of the other is codetermined by the CSCL environment's sociability. Sociability, social space, and social presence constitute the theoretical framework for research on social interaction in CSCL environments (see Figure 2). This is followed by a discussion of the more detailed aspects of our theoretical framework (see Figure 3 later in this article) leading to a number of hypothesized relationships which form a proposed research agenda.

\section{SOCIABILITY}

Sociability is an attribute of the CSCL environment; it is the extent to which it facilitates social interaction in the socioemotional dimension and, as desired result, the emergence of a sound social space, which is characterized by strong interpersonal relationships, trust, and a sense of cohesion. In other words, the sociability of a CSCL environment is its potential to encourage socioemotional interaction. The tangible (i.e., the physical and technological) elements that determine the sociability of the CSCL environment do not by themselves influence the quality, content, and intensity of the socioemotional interaction, but these elements can be designed in such a way that it becomes more likely that they can exert that influence. The kind of tangible elements we refer to are called social affordances (see the next section). The more the CSCL environment is sociable, the better it facilitates socioemotional interactions to take place that determine the group development of the CSCL learners. In that 


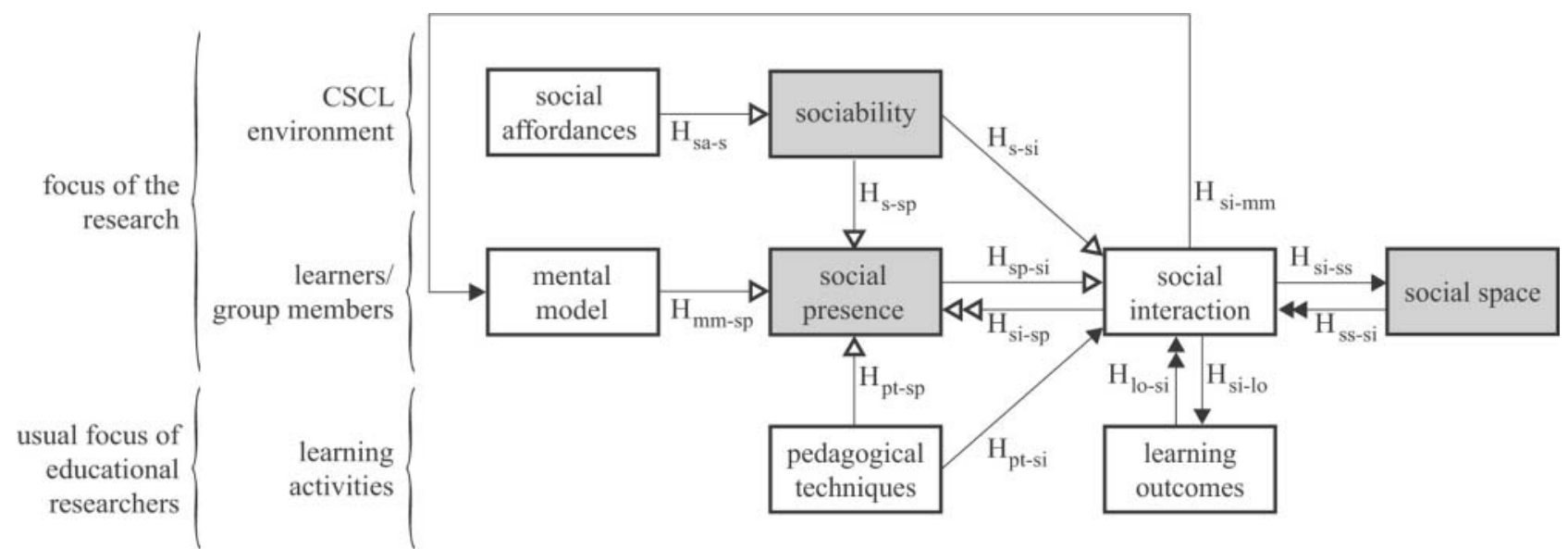

FIGURE 3 Hypothesized relationships centered on sociability, social presence and social space. Note. Each relationship (either affecting or reinforcing) is represented as an arrow and a label is placed alongside the arrow. The arrow indicates the direction of influence which is reflected in the subscript in the label. For example, the label $\mathrm{H}_{\mathrm{pt}-\mathrm{si}}$ refers to the relationship between pedagogical techniques (pt) and social interaction (si), and the direction is from pt to si. An open arrow means that the relationship exists by one of our definitions or is hypothesized in our article; a closed arrow means that the relationship is supported by the existing empirical literature. Not all relationships are supported by empirical evidence.

respect, it can be argued that some social software applications as Facebook are more sociable than traditional learning management systems as WebCT and Blackboard (see, e.g., Selwyn, 2007). This has led educators (and software developers) to supplement those traditional environments with social software (e.g., recently Blackboard connects to a variety of social software applications through Blackboard Connect; see Blackboard, 2012) or even abandon them entirely and to rely solely on particular configurations of social media applications that together function as a CSCL environment (e.g., Laru, Näykki, \& Järvelä, 2012). Although the main educational reason for using Web 2.0 technologies is still to promote cognitive interaction - rather than socioemotional interactions - the latter kind of interaction seems to be greatly supported by these social media. Augustsson (2010) highlighted this point: "Web 2.0 technology is well suited for collaborative learning, collective knowledge building, knowledge management, social networking and social interaction, which means that both course participants and teachers become more active and personally involved" (p. 197).

So far in our discussion, sociability has been viewed as a technological attribute of the CSCL environment and, thus, this perspective on sociability is defined in terms of the sociotechnological system (cf. Gao, Kang, Fan, Dai, \& Wu, 2008). On this view, sociability can be enhanced by carefully designing and implementing the tangible elements that determine it. To the extent that the technology affords a socially meaningful and satisfying interaction, the CSCL environment will motivate and sustain social activity and social benefits (Laffey, Lin, \& Lin, 2006). However, the domain of computer-human interaction offers another perspective on sociability. For example, Preece (2000), studying online communities, defined sociability as that characteristic of a community concerned with planning and developing under- standable and acceptable social policies to support the community's purpose. Her sociability concept deals with three components that guide social interaction: community purpose, the people who participate, and policies.

For Preece, every social group should have some form of regulation determining how members should interact. Rules define the regulation, and policies underlie the rules. In other words, sociability is seen as an attribute of the social system rather than of the sociotechnological system. Here, the community purpose, policies, and rules form the intangible elements that determine the sociability of the online community; they are intangible because they are neither physical nor technological. Sociability can be enhanced by carefully defining the community's purpose, its policies, and its rules. Of interest, Preece believed that in educational communities sociability should be aimed at on-task interactions and that off-task interaction should be discouraged. In the next section we integrate both sociotechnological and social perspectives on sociability.

\section{Integration of Both Perspectives}

The two perspectives on sociability (sociability as an attribute of the sociotechnological system and sociability as an attribute of the social system) has resulted into two lines of research: one favoring the sociotechnological system perspective focusing on CSCL environments but that can also be applied to online communities (e.g., Abedin, 2009; Smith, 2006; Yang, 2007), and one favoring the social system perspective focusing on online communities but that can also be applied to CSCL environments (e.g., Heikkinen, 2007; Stockdale \& Thomson, 2008). However, not all sociability research shows this clear distinction. Most research combines the two perspectives with one being dominant (e.g., Gao et al., 
2008). Because the two perspectives complement each other, approaches for enhancing the CSCL environment's sociability should take both into account. To do so, Preece's three sociability components are here reinterpreted for the CSCL context as she did not study CSCL groups per se:

1. Purpose: The goal of the collaborative learning activity should be stated clearly so that all members will have the same expectations of what has to be accomplished in the group, thereby avoiding frustration. Frustration will negatively impact the group dynamics and, thus, the forming of a sound social space.

2. People: To enhance the collaborative learning activity, group members should fulfill different roles within the group. Assigning or assuming roles is a pedagogical technique to support both positive interdependence among the members and individual accountability (cf. Strijbos \& Laat, 2010) so that all members participate in the learning task. From a community perspective, roles are important because they can strongly impact a community either positively or negatively. Roles that have been identified include moderators and mediators, professional commenters, provocateurs, general participants, and lurkers. In a successful CSCL group, some or all of these roles are fulfilled. The CSCL environment, therefore, must allow for defining roles and enable those privileges associated with the roles.

3. Policies: CSCL policies need not be different from policies in other online communities, encompassing similar rules, protocols, rituals, and "netiquette" (Shea, 1997). As a result, CSCL participants can be viewed as active members of a learning community (Palloff \& Pratt, 2007).

To summarize, sociability (which we see as an attribute of the CSCL environment) facilitates two important processes necessary for CSCL groups, namely, socioemotional interaction and, as a consequence, the emergence of a social space. The latter is elaborated later in this article, but first we discuss factors that affect the degree of a CSCL environment's sociability.

\section{Factors Affecting Sociability}

The tangible elements of a CSCL environment that determine the sociability of a CSCL environment are referred to as social affordances. Social affordances are those properties of the CSCL environment that act as social-contextual facilitators relevant for the learner's socioemotional interactions. When perceived, social affordances may initiate, encourage, and sustain social interaction in the socioemotional dimension in both task and nontask contexts. A quick example of what a social affordance device might be in the real-life setting is the coffee machine in the hallway of an office building (off-task context) or in the meeting room (on-task context).
Coffee machines promote impromptu encounters, and during these encounters people have informal conversations about anything from task-related problems to last night's football game or the hobbies they have (self-disclosure). Thus, these conversations contain fragments of both task-oriented and socioemotional content; as we mentioned before: Even in nontask settings it is still possible to have social interactions that serves the cognitive dimension by promoting group development. This special characteristic of the coffee machine is shared by water coolers and photocopiers and has led some researchers in the knowledge management domain to advice companies to surround employees with coffee bars, and so on, to promote informal knowledge transfer between individual employees (Sveiby, 2001).

One kind of social affordance is based on providing awareness information about the CSCL group informing each member, for example, about whether other members are currently online and available for real-time communication. Of course, the provision of awareness information should go along with integrated communication tools; otherwise, no conversations can be initiated. In general, various types of group awareness information may address a broad spectrum of activities being carried out by the CSCL group members. As long as socioemotional interaction can take place in response to the awareness information with respect to the activity, it does not matter whether the activity is task or non-task oriented. An example of the provision of taskoriented group awareness to CSCL groups is Janssen and Bodemer (2013) participation tool, which is designed to visualize group members' relative contributions to CSCL process, affording participants an awareness of one another's contributions and thus helping to coordinate these contributions.

Several researchers have found that factors other than social affordances in the technological environment influence perceptions of sociability. Abedin (2009) found that participants' perceptions of their own self-representation and their compatibility with the CSCL environment affected awareness of others and a sense of cohesion, thus indirectly affecting nontask sociability. Gao, Dai, Fan, and Kang (2010) found that social climate, benefits and purposes, the people participating, the richness of the interaction, self-presentation, and support for formal interactions all influence perceived sociability of social software.

\section{SOCIAL SPACE}

In line with Bales (1999), we view the group to which the CSCL group members belong as a network of interpersonal relationships that is continuously changing through the social interaction that takes place within the group. Furthermore, from a social network perspective (Katz, Lazer, Arrow, \& Contractor, 2004), we view each interpersonal relationship that exists between two group members as a tie that connects 
these two members - a tie that can be weak or strong. From this point of view, it is suggested that all these ties are spanning a space. Because this space is one that exists among the members of a group, it is designated a social space.

According to Forsyth (2009), group development leads to the establishment of a normative structure (encompassing rules, values and believes), an affective structure (encompassing mutual trust, group cohesiveness, and sense of community), a communication structure (defined as the routing of the information stream; in CSCL groups every member should communicate with all others), and a role structure (e.g., who of the members is the leader). However, not all four structures will come into existence at the instant when a CSCL group is formed. As the CSCL group begins, each member will try to come in terms with the requirements of their role (Forsyth, 2009). Along with this, the group begins to define the norms, the rules, and other structures that are needed in order to become a performing group (Tuckman \& Jensen, 1977).

Based upon the aforementioned considerations, social space is defined as the network of interpersonal/social relationships among group members embedded in the group's norms and values, rules and roles, beliefs and ideas (Kreijns, Kirschner, Jochems, \& Van Buuren, 2004). Although this definition puts the emphasis on the more structural aspects of the group, these structures must exist to some degree before a group may become a performing group. A performing group requires that the social space is sound. This is the case when the group structures manifest themselves by strong relationships, group cohesiveness, trust and respect, feelings of belonging, satisfaction, and a sense of community. With respect to strong relationships, Warketin, Sayeed, and Hightower (1997) found that relational links among team members were a significant contributor to the effectiveness of information exchange. Strong relationships may add to the group cohesiveness and feelings of belonging. Group cohesiveness is the tendency of a CSCL group to have a sense of unity while working on the group tasks and to satisfy the emotional needs of its members (Carron \& Brawley, 2000). A feeling of belonging - the feeling that one is connected and accepted by the other CSCL members - is important as it gives the group members a group identity (Goodenow, 1993; Osterman, 2000). Trust is defined as the cognitive and affective assurance of group members that they respect each other's interests and, therefore, can orient themselves toward each other's words, actions, and decisions with an easy conscience (Chang \& Lee, 2007; Emans, Koopman, Rutte, \& Steensma, 1996). Finally, Wegerif (1998) noted that

forming a sense of community, where people feel they will be treated sympathetically by their fellows, seems to be a necessary first step for collaborative learning. Without a feeling of community people are on their own, likely to be anxious, defensive and unwilling to take the risks involved in learning. (p. 48)

Thus, sense of community seems another quality that a sound social space should have.

Once a sound social space is established, it, in turn, reinforces and sustains the social interaction among members, enabling open critical dialogues that neither harm nor offend group members because they know and trust each other (Rourke \& Anderson, 2002). In a CSCL environment it promotes positive feelings such that learners benefit by experiencing a greater sense of well-being (Rovai, 2002). Furthermore, a sound social space contributes to a positive social climate/online-atmosphere within the group (Brandon \& Hollingshead, 1999; Rourke \& Anderson, 2002).To summarize, all the qualities of a sound social space satisfy the prerequisites for an optimal social context for collaborative learning:

\footnotetext{
Effective groups have several characteristics: the atmosphere is close and friendly; all members participate in the group; all members are committed to the group's goals; members listen to each other and share information; decisions are made by consensus; conflict is dealt with openly and resolved; members receive frank and objective feedback and feel free to express their feelings openly; there is a division of labour with shared leadership; and the group is aware of its own operations and able to monitor itself. (Cherrington, as cited by Finntrack Ltd, 2011, Characteristics of Effective Groups section)
}

\section{Factors Affecting Social Space}

As discussed in the previous section, sociability is the CSCL environment's potential to encourage socioemotional interaction. This potential must be exploited by the CSCL group members and, therefore, the desired result - the emergence of a sound social space - actually depends on the CSCL members. They determine whether they pursue that goal and are willing to fully exploit what the CSCL environment affords them in terms of sociability. Values and regulations that were originally external become internalized by individuals, ultimately being perceived by them as their own. Indeed, Preece (2001) remarked that "decisions about purpose, people and policies by community developers [i.e., the teachers or instructors] help determine the initial sociability of an online community. Later, as the community evolves an understanding of which social norms and policies are acceptable and which are not gradually becomes established" (p. 349). Finally, social presence is another variable affecting the degree to which a social space will emerge among the CSCL member and whether this space becomes sound; social presence is discussed in the next section. 


\section{SOCIAL PRESENCE}

To complete the theoretical framework, we must consider the CSCL members themselves and how they experience the other members. Short, Williams, and Christie (1976) coined the term social presence. They characterized communication media in terms of their potential to communicate verbal and non-verbal cues conveying socioemotional information in a way that the other is perceived as physically present. They defined social presence as the "degree of salience of the other person in the communication and the consequent salience of the interpersonal relationships" (p. 65).

Kim (2010) viewed social presence in education as a key to understanding the development of social relations and as a significant predictor of the learners achievement and satisfaction. Tu (2000), linking social learning theory to social presence, asserted that, because social presence is crucial for maintaining a high degree of online social interaction, it is also crucial for learning processes. Garrison and Arbaugh (2007) concluded from a literature review that although social presence alone will not ensure the development of critical discourse in online learning, it is difficult for such discourse to develop without the foundation of social presence.

Short et al.'s (1976) definition can be split into two parts: (a) "the salience of the other in the communication" and (b) the consequence of this, namely "the salience of the interpersonal relationship" (see also Kehrwald, 2008; Vanden Abeele, Roe, \& Pandelaere, 2007). In our model, the definition of social presence is restricted to the first part (i.e., the "realness" of the other); the second part (i.e., the salience of the interpersonal relationship) is viewed instead as one element of the social space, which is defined as the overall network of social relationships. By "realness," we refer to a sense that, although participants know that the other is not physically present in the communication, they nevertheless experience the feeling that they are - to some degree - so. Consistent with Short et al., our definition of social presence is an antecedent variable to the emergence of a social space. Social presence is defined as the degree of psychological sensation in which the illusion exists that the other in the communication appears to be a "real" person (Kreijns, Kirschner, Jochems, \& Van Buuren, 2011).

\section{Factors Affecting Social Presence}

Short et al. (1976) initially held that the degree of social presence of a telecommunication medium was determined solely by the objective technological characteristics of a medium. Although they subsequently relaxed their view to include subjective qualities of a medium, they still favored the objective perspective when it came to theoretically explaining variations in social presence between different media. For this reason, the kind of social presence that they proposed can be designated as technologically determined (see also Kehrwald, 2008). In contrast, Gunawardena (1995) showed in her studies that it is not the media characteristics that determine the degree of perceived social presence, but rather that participants in conferences create social presence by projecting their identities through carefully drafted messages. These messages help them build online communities because the messages help them to be perceived as real persons. In other words, Gunawardena found that social presence can be cultured, a finding that was already suggested by Johansen, Valee, and Spangler (1988) and further explored by ScollinsMantha (2008). This kind of social presence (Gunawardena, 1995; Tu, 2000) can be designated as socially determined.

We, however, see social presence as codetermined, on one hand, by the physical characteristics of the CSCL environment and, on the other hand, by a contingency of social influence factors such as social context, social processes, and so forth (cf. Spears, Postmes, Wolbert, Lea, \& Rogers, 2000). Therefore, in our view, the degree of social presence is influenced both by sociability and by the techniques used by teachers to allow the CSCL members to get to know each other and to form individual impressions of each other (Aragon, 2003; Garrison, Anderson, \& Archer, 2000; Gunawardena, 1995). According to Walther's (1993a) social information processing theory, accumulated relational messages originating from previous episodes of social interaction with other group members contribute to the forming of individuating impressions of those others. This mental model affects the degree of the social presence experienced. Indeed, it makes a difference if CSCL members already know the others in the conversation. If this is the case, then this may increase the degree of social presence (Tu, 2002).

\section{THE MODEL}

The theoretical framework centers on the three elements, as depicted in Figure 3: sociability, social presence, and social space. The definition or description of all the variables that are depicted in Figure 3 and their potential measures are listed in Table 1.

\section{Arguments Underlying the Hypothesized Relationships}

In this section, we discuss the arguments underlying the relationships between the variables in Figure 3. To present a clearer overview, we present a model with a linear appearance, and we discuss these one by one in a linear order. However, we assume that more interactive and circular processes take place. Whereas a number of researchers have found strong and weak empirical evidence for some of the hypothesized relationships, it is nevertheless important to conduct further research so to support those findings and to provide evidence for those relationships that have not yet been researched. 
TABLE 1

The Variables in Figure 3 and Their Potential Measures

\begin{tabular}{|c|c|c|}
\hline Variable & Definition/Description & Measures \\
\hline Social affordances & $\begin{array}{l}\text { Social affordances are those properties of the CSCL environment } \\
\text { that act as social-contextual facilitators relevant for the } \\
\text { learner's socioemotional interactions. Social affordance can be } \\
\text { tangible (e.g., group awareness delivering tools) or intangible } \\
\text { (e.g., the policies and rules in the CSCL groups). }\end{array}$ & Not applicable \\
\hline Sociability & $\begin{array}{l}\text { The extent to which CSCL facilitates social interaction in the } \\
\text { socio-emotional dimension and through it, as a desired result, } \\
\text { the emergence of a sound social space. }\end{array}$ & $\begin{array}{l}\text { Kreijns et al. (2007) developed a Sociability Scale. A sample } \\
\text { item is: "We reached a good understanding on how we had } \\
\text { to function." }\end{array}$ \\
\hline Mental model & $\begin{array}{l}\text { The mental model is the individuating impression/internal } \\
\text { representation of the other CSCL member. Mental models of } \\
\text { the others are formed through a process of impression } \\
\text { formation. }\end{array}$ & $\begin{array}{l}\text { Walther (1993b) developed a quantitative measure of } \\
\text { impression formation. }\end{array}$ \\
\hline Social presence & $\begin{array}{l}\text { Social presence is the degree of psychological sensation in which } \\
\text { the illusion exists that the other in the communication appears } \\
\text { to be a "real" person. }\end{array}$ & $\begin{array}{l}\text { A number of social presence measures exist. Whereas some of } \\
\text { them seems to assess the degree of "realness" of the other, } \\
\text { the majority of the social presence measures assesses } \\
\text { aspects that would here be associated with social space. The } \\
\text { Social Presence Scale developed by Kreijns et al. (2011) } \\
\text { assesses the "realness" of the other in the communication. A } \\
\text { sample item is "When I have real-time conversations in this } \\
\text { CSCL environment, I feel that I deal with very real persons } \\
\text { and not with abstract anonymous persons." }\end{array}$ \\
\hline $\begin{array}{l}\text { Pedagogical } \\
\text { techniques }\end{array}$ & $\begin{array}{l}\text { CSCL pedagogical techniques are required to encourage social } \\
\text { interaction in the cognitive and in the socio-emotional } \\
\text { dimension. These techniques should also "culture" social } \\
\text { presence. }\end{array}$ & Not applicable \\
\hline Social interaction & $\begin{array}{l}\text { Social interaction is the process in which messages are exchanged } \\
\text { between members of the CSCL group. These messages may } \\
\text { carry task-oriented or socio-emotional oriented content. }\end{array}$ & $\begin{array}{l}\text { Bales (1999) developed the Systematic Multiple Level } \\
\text { Observation of Groups (SYMLOG) system for categorizing } \\
\text { the different types of social interaction that may occur in } \\
\text { small groups. }\end{array}$ \\
\hline $\begin{array}{l}\text { Learning } \\
\text { outcomes }\end{array}$ & $\begin{array}{l}\text { This is a main goal of CSCL: the learning outcomes of each } \\
\text { individual CSCL member as well as that of the CSCL group as } \\
\text { a whole. Learning outcomes refer to the particular knowledge, } \\
\text { skills, attitudes and behaviors that are acquired during } \\
\text { collaborative learning }\end{array}$ & $\begin{array}{l}\text { The extant educational literature presents many direct and } \\
\text { indirect measures that assess individual and group learning } \\
\text { outcomes (e.g., Chan \& van Aalst, 2004; Law, 2005). }\end{array}$ \\
\hline Social space & $\begin{array}{l}\text { The social space is the network of interpersonal/social } \\
\text { relationships among group members embedded in the group's } \\
\text { norms and values, rules and roles, beliefs and ideas. The social } \\
\text { space is sound when these group structures manifest } \\
\text { themselves by strong relationships, group cohesiveness, trust } \\
\text { and respect, feelings of belonging, satisfaction, and a sense of } \\
\text { community. }\end{array}$ & $\begin{array}{l}\text { Kreijns, Kirschner, Jochems, and van Buuren (2004) developed } \\
\text { a Social Space Scale that assesses the soundness of the } \\
\text { social space. A sample item is "This CSCL environment } \\
\text { allows for spontaneous informal conversations." }\end{array}$ \\
\hline
\end{tabular}

Note. $\mathrm{CSCL}=$ computer-supported collaborative learning.

Social affordances influence sociability $\left(H_{\text {sa-s }}\right)$. Social affordances are hypothesized to contribute to the sociability of the CSCL environment. The critical question is, Which social affordances are effective, and how do they contribute to perceived sociability? The hypothesis is quite intuitive; for example, and as already mentioned, the social media application Facebook is generally perceived to be higher in sociability than WebCT or Blackboard because, in contrast to these two learning management systems, Facebook emphasizes making connections with strangers and engaging in small talk with acquaintances. It supports these aims in various ways through tools like presenting lists that draw members' attention to potential con- nections or by presenting members with short messages in which you informs them about their friends' whereabouts. These tools are social affordances. Thus, the different affordances may lead to differences in perceived sociability. Indeed, Keenan and Shiri (2009) found that Facebook, Myspace, LinkedIn, and Twitter differ in their sociability because of their particular affordances for social interaction. Oksanen and Hämäläinen (2012) found in a comparison between two different kinds of CSCL environments that "the level of perceived sociability was largely higher in serious game setting [i.e., 'Game Bridge'] than in the more traditional, asynchronous type of virtual environment" (p. 364). 
Sociability influences social interaction $\left(H_{s-s i}\right)$. We have posited throughout this article that sociable CSCL environments will enhance social interaction among CSCL participants. This follows from Donath's (1997) reasoning that online environments such as CSCL environments should have the social qualities of vibrancy and viability. Such sociability (which is promoted by social affordances in the CSCL environment) promotes greater and more socioemotional interaction. The study of Keenan and Shiri (2009) supported the relationship as they linked the sociability of four social media applications (Facebook, Myspace, LinkedIn, and Twitter) with the high degree of social interaction that these applications facilitated. Charlton, Devlin, Marshall, and Drummond (2010) explored the influence of a status awareness tool called CommonGround on the degree of social interaction that is happening in a virtual team consisting of students collaborating with industrial clients. CommonGround informed all teammates about the current activities of each other. The researchers found that CommonGround offered "a means to foster group interaction and community building by providing a centralised application through which students can interact and explore the personal profiles and work patterns of their team mates" (p. 184).

Sociability influences social presence $\left(H_{s-s p}\right)$. Kear (2010) argued that "social presence is influenced by features of the communication environment, and also by the behaviours of participants within this environment. Moreover, features of the environment can affect how people behave towards each other" (p. 547). In her study on the adoption of WebCT as an online teacher professional development system, Smith (2006) found that sociability had a strong positive relationship with social presence, thereby supporting the hypothesis that "the emergence of social presence would be highly dependent upon a system's ability to facilitate the social interaction within the web-based course" (p. 83). Her finding was reaffirmed by Yang (2007), investigating students' adoption of WebCT: "Sociability is the most significant predictor of social presence" (p. 70). Thus, in so far as WebCT was perceived as sociable, it contributed to the degree of social presence of the participating students.

The extent to which mental models of the members are formed influences the degree of perceived social presence $\left(H_{m m-s p}\right)$. Rettie (2005) stated that "although most research on social presence has been done with strangers, the salience of the other is likely to be less dependent on cues when people already know one another" (p. 358). She thus suggested that knowing others influences the degree of social presence and that once a mental model of the other exists, communication cues become less important to sustaining social presence (see also Tu, 2002). However, research is needed to confirm the relationship between mental model and social presence.
The application of CSCL pedagogies influences the degree of perceived social presence $\left(H_{p t-s p}\right)$. Gunawardena (1995) stated that social presence can be cultured and that instructors are responsible for this. Whipp and Lorentz (2009) developed a series of guidelines for how teachers and instructors can enhance social presence among students, including sharing their knowledge from research, telling personal experiences, and providing helpful information. Also, when students ask for help, they should provide this help as quickly as possible (Aragon, 2003). Scollins-Mantha (2008) composed a very complete list of recommendations for cultivating social presence in the online learning classroom. For example, she recommends ice-breakers and welcome messages at the start of the virtual class. However, no research has yet been conducted that such techniques will indeed lead to an increase of social presence.

The degree to which social presence of the members is perceived influences the degree of social interaction among them $\left(H_{s p-s i}\right)$. This relationship has been suggested by many social presence researchers, most notably $\mathrm{Tu}$ (2000): "Social presence is required to enhance and foster online social interaction, which is the major vehicle of social learning" (p. 27). Inspired by the work of Garrison et al. (2000), Stodel, Thompson, and MacDonald (2006) asserted that the function of social presence is "to facilitate the attainment of the cognitive learning objectives by supporting critical thinking in a community of learners, as well as the affective learning objectives by making the group interactions enjoyable and rewarding" (p. 3). Tu and McIsaac (2002) found social presence to be vital for influencing online interaction. Their findings were based on a qualitative study in which the three different communication media of FirstClass were compared: e-mail, bulletin board, and real-time chat. Also, Shen, Yu, and Khalifa (2006) provided strong support that in four different virtual communities of interest social presence positively influenced social interaction and, thus, the degree of community participation.

The application of CSCL pedagogies influences the degree of social interaction among the members $\left(H_{p t-s i}\right)$. In the Introduction section, we argued that, without a specific CSCL pedagogy, social interaction among group members will not arise. Much CSCL is conducted precisely to formulate such CSCL pedagogy. Pedagogies that are successful at enhancing social interaction include the application of pedagogical scripting (e.g., Dillenbourg \& Tchounikine, 2007; Fischer et al., 2013) and predefined roles (e.g., Strijbos \& de Laat, 2010).

The extent to which social interaction is present among group members influences the likelihood of establishing a social space $\left(H_{s i-s s}\right)$. It is unthinkable that in the absence of social interaction any social phenomena will exist, including a social space. Social interaction in the 
socioemotional dimension is, thus, a precursor to the emergence of a social space.

The combined relationship $\mathrm{H}_{\mathrm{s} \text {-si }}$ and $\mathrm{H}_{\text {si-ss }}$ (i.e., $\mathrm{H}_{\mathrm{s} \text {-si-ss }}$ ) represents our definition of sociability, namely, the extent to which a CSCL environment is able to facilitate the emergence of a social space. For CSCL groups to become a performing group, this social space should be sound. An empirical study by Oksanen and Hämäläinen (2012), using an earlier version of our proposed model, supported the combined relationship $\mathrm{H}_{\mathrm{s}-\mathrm{si} \text {-ss }}$. They found that in the collaborative game environment Game Bridge the sociability of the game "facilitated socioemotional processes (such as trust building and a sense of community)" (p. 368). They also found that sociability led to the "emergence of a positive atmosphere for group formation, and further for social interaction and collaborative activities" (p. 368).

It is also expected that social presence will contribute to the emergence of a social space, thus suggesting the combined relationship $\mathrm{H}_{\mathrm{sp}-\mathrm{si}}$ and $\mathrm{H}_{\text {si-ss }}$ (i.e., $\mathrm{H}_{\text {sp-si-ss }}$ ). Walker (2007) studied the relationships $\mathrm{H}_{\text {sp-si }}$ and the combined relationship $\mathrm{H}_{\text {sp-si-ss }}$ and found that social presence supported by a multiuser virtual reality environment promoted social interaction in discussion forums, which in turn promoted development of sense of community. The combined relationship $\mathrm{H}_{\text {sp-si-ss }}$ was also studied by Aragon (2003), Gunawardena (1995), Gunawardena and Zittle (1997), and Stodel et al. (2006). Rourke, Anderson, Garrison, and Archer (1999) found that high levels of social presence created a learning environment that was perceived as warm, collegial, and approachable.

The combined relationship $\mathrm{H}_{\mathrm{pt}-\mathrm{si}}$ and $\mathrm{H}_{\mathrm{si} \text {-ss }}$ (i.e., $\mathrm{H}_{\mathrm{pt}-\mathrm{si}-\mathrm{ss}}$ ) represents the hypothesized relationship between CSCL pedagogies and social space. In fact, this relationship comprises what Gunawardena (1995), Rourke and Anderson (2002), and many other social presence researchers have asserted, namely, that pedagogical techniques are needed to create interaction and social climate. For example, Gunawardena recommended that "conference moderators should facilitate discussions by recognizing all contributions initially, summarizing frequently, and weaving ideas together" (p. 163) and to "start the conference with introductions and social exchanges if the system used is a listserv, or create a separate area for social chit chat in a conferencing system" (p. 163) to create social presence that will result in feelings of a sense of community among the members.

The extent to which social interaction is present among group members influences learning outcomes $\left(H_{\text {si-lo }}\right)$. Social interaction in the cognitive dimension will influence the learning outcomes of each individual CSCL member as well as that of the CSCL group as a whole. This relationship is the very reason why collaborative learning is deployed (Kearsley, 1995; Laurillard, 2002; Lethinen, Hakkarainen, Lipponen, Rahikainen, \& Muukkonen, 2001; Vygotsky, 1978). Collaborative learning provides the social context where learners may become actively involved in $\operatorname{cog}$ nitive processes such as grounding, critical thinking, and knowledge construction, which benefit deep learning and retention of the concepts learned (Biggs, 1987; Johnson et al., 1985).

The combined relationship $\mathrm{H}_{\mathrm{sp}-\mathrm{si}}$ and $\mathrm{H}_{\mathrm{si}-\mathrm{lo}}$ (i.e., $\mathrm{H}_{\mathrm{sp} \text {-si-lo }}$ ) represents the degree to which the social presence of the members is perceived influences social interaction and the degree to which social interaction influences learning outcomes. The reason that social presence was introduced as a concept in online collaborative learning is that it affects the degree of social interaction $\left(\mathrm{H}_{\mathrm{sp} \text {-si }}\right)$ and, through this interaction, learning $\left(\mathrm{H}_{\text {si-lo }}\right.$; Gunawardena, 1995; Kim, 2010; Tu, 2000). Kim, Kwon, and Cho (2011) started to investigate factors that enhance social presence and learning outcomes (i.e., the learner's satisfaction) in higher education. They found media integration and the instructor's quality teaching were significant predictors of social presence and the learner's satisfaction. Finally, Hostetter (2012) reported that "the regression model revealed that students with higher demonstrations of social presence in discussion forum posts had statistically significantly higher ratings on the CAT [i.e., Classroom Assessment Technique]. This seems to indicate that social presence influences student outcomes on written assignments" (p. 912). More research is needed to investigate the effects of social presence on learning outcomes.

Finally, our model posits that the application of CSCL pedagogies will influence the degree of social interaction among the members and the degree to which social interaction influences learning outcomes (the combined relationship $\mathrm{H}_{\text {pt-si }}$ and $\mathrm{H}_{\text {si-lo }}$, i.e., $\mathrm{H}_{\text {pt-si-lo }}$ ). Of course, pedagogical techniques that apply to collaborative learning must stimulate social interaction between students or learning will not occur (Wiley, 2006). All research efforts in the domain of CSCL are, ultimately, focused on achieving thus that aim.

The degree of social interaction among members influences the degree to which the mental models of the group members are formed $\left(H_{s i-m m}\right)$. Social interaction involves exchanging messages, which makes it also possible to build op a mental model of the others involved in the interaction (Walther, 1996). More precisely, Walther (1996) found that knowing the others in the group as well as something about them can be accomplished through message accumulation (through social interaction) in a text-based, computer-mediated communication environment. These messages, over time, help the CSCL members build mental models of each other. These metal models of the others are important as found by Tu and McIsaac (2002), who reported that familiarity with others positively influences social presence, thereby supporting relationship $\mathrm{H}_{\mathrm{si}-\mathrm{mm}}$.

The establishment of a sound social space is hypothesized to reinforce social interaction $\left(H_{s p-s i}\right)$. Only when strong personal relationships, sense of community, and 
trust are established will members be willing to participate in collaborative learning and share knowledge (Von Krogh, Nonaka, \& Ichijo, 2000). Rovai (2002) pointed out that feelings of community can increase the flow of information between (all) learners while encouraging support, commitment to group goals, cooperation among members, and satisfaction with group efforts. Also, according to Garrison and Anderson (2003), "social presence means creating a climate that supports and encourages probing questions, scepticism and the contribution of more explanatory ideas" (p. 50). In fact, they suggested a more complex path which encompasses the combined relationship $\mathrm{H}_{\text {sp-si-ss }}$ (social presence leads to a social space, preferably a sound social space that they referred to as the supporting climate) and $\mathrm{H}_{\mathrm{ss}-\mathrm{si}}$ (a sound social space supports social interaction in the cognitive dimension). The statements here suggest that a sound social space reinforces social interaction. But again, more research is needed how this reinforcement is actually accomplished.

Progression toward positive learning outcomes is hypothesized to reinforce social interaction $\left(H_{l o-s i}\right)$. When CSCL members perceive that their learning is resulting in outcomes that are in the right direction (e.g., they can provide a solution for the problem), then this will motivate the members to put extra effort in their learning and, thus, social interaction is reinforced. Here, too, more research is needed to provide evidence of this reinforcement and to document how it is actually accomplished.

The extent to which social interaction is present among group members influences the degree of perceived social presence $\left(H_{s i-s p}\right)$. Murphy and Cifuentes (2001) found that online learner interaction is essential for creating a sense of social presence. In other words, social presence is influenced by the behavior and interactions of the participants. Indeed, Tu and McIsaac (2002) argued that increasing online interaction results in increased social presence: "an increase in the level of online interaction occurs with an improved level of social presence" (p. 131). This can be fostered by taking learner characteristics into account, selecting appropriate computer-mediated communication media (suggesting the combined relationship $\mathrm{H}_{\text {sa-s-sp }}$ ), and applying appropriate instructional elements to course design (suggesting the relationships $\mathrm{H}_{\mathrm{pt}-\mathrm{sp}}$ and $\mathrm{H}_{\mathrm{pt-si}}$ ).

\section{DISCUSSION AND CONCLUSION}

Sociability, social space and social presence are key elements of CSCL that provide insights in how to increase the chance that social interaction will occur among members of a collaborative learning group. Sociability and social presence encourage social interaction; social space reinforces it.

An examination of the research history of the concept of sociability yields two main perspectives: a technologi- cal system perspective (advanced by Kreijns, Kirschner, \& Jochems, 2002) and a social system perspective (advanced by Preece, 2000). The former was developed in the area of CSCL environments together with social presence and social space. The latter was developed in the area of online communities along with usability issues like ease of use, learnability, chance of making errors, and so on. Both perspectives must be combined to provide insights into how to increase social interaction in the cognitive dimension as well as in the socioemotional dimension. Although the concepts sociability, social presence, and social space have been applied only to CSCL in this article, it is easy to expand them and apply them to other sociotechnological systems such as social software (e.g., Facebook, Twitter), online gaming environments, online communities (of practice), virtual learning networks, and even 3D virtual environments (e.g., Second Life). In fact, that is what some scholars are already doing (see, e.g., Gao et al., 2010; Pan, Kuo, \& Lee, 2007; Stockdale \& Thompson, 2008).

A sound social space makes it possible for group members to gain a feeling of relatedness, group cohesiveness, trust, and respect for each other. In a review study by Wang and Noe (2010) on knowledge sharing behavior in organizations and teams, factors as trust and social cohesion play a key role. They concluded that the more cohesiveness and trust between members, the more knowledge sharing occurred.

\section{FUTURE RESEARCH}

The model presented here should be tested through a systematic series of empirical experiments to investigate whether the hypotheses specified in the theoretical framework in Figure 3 hold. Although several researchers have found support for several hypothesized relationships, some researchers have found contradictory findings. If further support for the hypothesized relationships can be found, the theoretical framework can be used as a foundation framework for designing sociable CSCL environments, and the importance of social presence for CSCL will be affirmed. Future CSCL environments need to be sociable, which means that they need to encourage and support sociability, social presence, and social space. All these are needed for CSCL to become a motivating environment for collaboration.

\section{REFERENCES}

Abedin, B. (2009). Investigating non-pedagogical sociability of asynchronous computer supported collaborative learning environments (Unpublished doctoral dissertation). Sydney, Australia: University of New South Wales.

Abedin, B., Daneshgar, F., \& D'Ambra, J. (2012). Do nontask interactions matter? The relationship between nontask sociability of computer supported collaborative learning and learning outcomes. British Journal of Educational Technology, 43, 385-397. 
Aragon, S. R. (2003). Creating social presence in online environments. New Directions for Adult and Continuing Education, 100, 57-68. doi: $10.1002 /$ ace. 119

Augustsson, G. (2010). Web 2.0, pedagogical support for reflexive and emotional social interaction among Swedish students. Internet and Higher Education, 13, 197-205. doi:10.1016/j.iheduc.2010.05.005

Bagherian, F., \& Thorngate, W. (2000). Horses to water: Student use of course newsgroups. FirstMonday, 5. Retrieved from http://www.first monday.org/htbin/cgiwrap/bin/ojs/index.php/fm/article/view/779/688

Bales, R. F. (1999). Social interaction systems: Theory and measurement. New Brunswick, NJ: Transaction. doi:10.1037//1089-2699.4.2.199

Biggs, J. B. (1987). Student approaches to studying and learning. Hawthorne, Victoria: Australian Council for Educational Research.

Blackboard. (2012). Communicating with students in a Web 2.0 World. Retrieved from http://www.blackboard.com/Platforms/Connect/Resources/ Research.aspx

Brandon, D. P., \& Hollingshead, A. B. (1999). Collaborative learning and computer-supported groups. Communication Education, 18, 109-126. doi:10.1080/03634529909379159

Carron, A. V., Brawley, L. R. (2000). Cohesion: Conceptual and measurement issues. Small Group Research, 31, 89-106. doi:10.1177/ 104649640003100105

Chan, C. K. K., \& van Aalst, J. (2004). Learning, assessment and collaboration in computer-supported enviroments. In J. W. Strijbos, P. A. Kirschners, \& R. L. Martens (Eds.), What we know about CSCL and implementing it in higher education (pp. 87-112). Amsterdam, The Netherlands: Kluwer Academic. doi:10.1007/1-4020-7921-4

Chang, H. M. \& Lee, S. T. (2007). Students' Trust relationships in a computer supported collaborative learning (CSCL). In T. Bastiaens \& S. Carliner (Eds.), Proceedings of World Conference on E-Learning in Corporate, Government, Healthcare, and Higher Education 2007 (pp. 2001-2003). Chesapeake, VA: AACE.

Charlton, T., Devlin, M., Marshall, L., \& Drummond, S. (2010). Encouraging interaction and status awareness in undergraduate software engineering projects: The role of social networking services. In Proceedings of the 1st annual engineering education conference (EDUCON): The future of global learning in Engineering Education (pp. 179-184). Madrid, Spain: IEEE Education Society. doi:10.1109/EDUCON.2010.5492580

Dillenbourg, P., \& Tchounikine, P. (2007). Flexibility in macro-scripts for computer-supported collaborative learning. Journal of Computer Assisted Learning, 23, $1-<$ arr263264 > doi:10.1111/j.1365-2729.2007.00191.x

Donath, J. S. (1997). Inhabiting the virtual city: The design of social environments for electronic communities (Unpublished doctoral dissertation). Cambridge, MA: MIT Press. Retrieved from http://smg.media. mit.edu/people/judith/Thesis/

Emans, B., Koopman, P., Rutte, C., \& Steensma, H. (1996). Teams in organisaties: Interne en externe determinanten van resultaatgerichtheid [Teams in organizations: Internal and external determinants of outcome orientation]. Gedrag en Organisatie, 9, 309-327.

Finntrack Ltd (2011). Group development. Retrieved from http://finntrack. co.uk/leadership/people_and_org/grp8.htm

Fischer, F., Kollar, I., Stegmann, K., \& Wecker, C. (2013). Toward a script theory of guidance in computer-supported collaborative learning. Educational Psychologist, 48, 56-66.

Forsyth, R. F. (2009). Group dynamics (5th ed.). Belmont, CA: Cengage Learning. doi:10.4135/9781412956253

Gao, Q., Dai, Y., Fan, Z., \& Kang, R. (2010). Understanding factors affecting perceived sociability of social software. Computers in Human Behavior, 26, 1846-1861. doi:10.1016/j.chb.2010.07.022

Gao, Q., Kang, R., Fan, Z., Dai, Y., \& Wu, S. (2008, July). Understanding sociability of social software: An exploratory study. Paper presented at the 2nd International Conference on Applied Ergonomics, Las Vegas, NV.

Garrison, D. R. \& Anderson, T. (2003). E-learning in the 21st century. London, UK: Routledge Falmer.
Garrison, D. R., Anderson, T., \& Archer, W. (2000). Critical thinking in a text-based environment: Computer conferencing in higher education. Internet and Higher Education, 2, 87-105. doi:10.4324/9780203166093

Garrison, D. R., \& Arbaugh, J. B. (2007). Researching the community of inquiry framework: Review, issues, and future directions. Internet \& Higher Education, 10, 157-172.

Gilbert, L., \& Moore, D. R. (1998). Building interactivity into web-courses: Tools for social and instructional interaction. Educational Technology, $38(3), 29-35$

Goodenow, C. (1993). The psychological sense of school membership among adolescents: Scale development and educational correlates. Psychology in the Schools, 30, 70-90. doi:10.1002/1520-6807(199301) 30:1<79::AID-PITS2310300113>3.0.CO;2-X

Gunawardena, C. N. (1995). Social presence theory and implications for interaction and collaborative learning in computer conferences. International Journal of Educational Telecommunications, 1, 147-166.

Gunawardena, C. N., \& Zittle, F. (1997). Social presence as a predictor of satisfaction within a computer mediated conferencing environment. American Journal of Distance Education, 11(3), 8-25. doi:10.1080/08923649709526970

Heikkinen, M. (2007, Feb. 18-20). Power and support in the net-Sociability on an internet based rehabilitation course for people with MS disease. In P. Kommers \& P. Asaías (Eds.), IADIS international conference on web based communities (pp. 368-372). Salamanca, Spain.

Hiltz, S. R. (1994). The virtual classroom: Learning without limits via computer networks. Norwood, NJ: Ablex.

Hostetter, C. (2012). Social presence and learning outcomes. In T. Amiel \& B. Wilson (Eds.), Proceedings of the world conference on educational multimedia, hypermedia and telecommunications 2012 (pp. 912-919). Chesapeake, VA: AACE.

Janssen, J., \& Bodemer, D. (2013). Coordinated computer-supported collaborative learning: Awareness and awareness tools. Educational Psychologist, 48, 40-55.

Johansen, R., Vallee, J., Spangler, K. (1988). Teleconferencing: Electronic group communication. In R. S. Cathcart \& L. A. Samovar (Eds.), Small group communication: A reader (5th ed., pp. 140-154). Menlo Park, CA: Institute for the Future.

Johnson, R. T., Johnson, D. W., \& Stanne, M. B. (1985). Effects of cooperative, competitive, and individualistic goal structures on computerassisted instruction. Journal of Educational Psychology, 77, 668-677. doi:10.1037//0022-0663.77.6.668

Katz, N., Lazer, D., Arrow, H., \& Contractor, N. (2004). Network theory and small groups. Small Group Research, 35, 307-332. doi:10.1177/ 1046496404264941

Kear, K. (2010, May). Social presence in online learning communities. In L. Dirckinck-Holmfeld, V. Hodgson, C. Jones, M. de Laat, D. McConnell, \& T. Ryberg (Eds.), Proceedings of the 7th international conference on networked learning 2010 (pp. 1-8). Aalborg, Denmark: Aalborg University.

Kearsley, G. (1995). The nature and value of interaction in distance learning. (ACSDE Research Monograph No. 12, pp. 83-92). University Park: Pennsylvania State University, American Center for the Study of Distance Education.

Keenan, A., \& Shiri, A. (2009). Sociability and social interaction on social networking websites. Library Review, 58, 438-450. doi:10.1108/ 00242530910969794

Kehrwald, B. (2008). Understanding social presence in text-based online learning environments. Distance Education, 29(1), 89-106. doi: $10.1080 / 01587910802004860$

Kim, J. (2010). Developing an instrument to measure social presence in distance higher education. British Journal of Education Technology, 42, 763-777. doi:10.1111/j.1467-8535.2010.01107.x

Kim, J., Kwon, Y., \& Cho, D. (2011). Investigating factors that influence social presence and learning outcomes in distance higher education. Computers \& Education, 57, 1512-1520. doi:10.1016/j.compedu.2011.02.005 
Kreijns, K., Kirschner, P. A., \& Jochems, W. (2002). The sociability of computer-supported collaborative learning environments. Journal of Education Technology \& Society, 5, 8-22. Retrieved from http://www.ifets.info/journals/5_1/kreijns.pdf. doi:10.1007/b105100

Kreijns, K., Kirschner, P. A., \& Jochems, W. (2003). Identifying the pitfalls for social interaction in computer-supported collaborative learning environments: A review of the research. Computers in Human Behavior, 19, 335-353. doi:10.1016/S0747-5632(02)00057-2

Kreijns, K., Kirschner, P. A., Jochems, W., \& Van Buuren, H. (2004). Measuring perceived quality of social space in distributed learning groups. Computers in Human Behavior, 20, 607-632. doi:10.1016/j.chb.2003.11. 002

Kreijns, K., Kirschner, P. A., Jochems, W., \& Van Buuren, H. (2007). Measuring perceived sociability of computer-supported collaborative learning environments. Computers \& Education, 49, 176-192. doi:10.1016/ j.compedu.2005.05.004

Kreijns, K., Kirschner, P. A., Jochems, W., \& Van Buuren, H. (2011). Measuring perceived social presence in distributed learning groups. Education and Information Technologies, 16, 365-381 doi:10.1007/s10639010-9135-7

Laffey, J. M, Lin, G.-Y. \& Lin, Y. -M. (2006). Assessing Social Ability in Online Learning Environments. Journal of Interactive Learning Research, 17, 163-177. Chesapeake, VA: AACE

Laru, J., Näykki, P., \& Järvelä, S. (2012). Supporting small-group learning using multiple Web 2.0 tools: A case study in the higher education context. Internet and Higher Education, 15(1), 29-38. doi:10.1016/j.iheduc.2011.08.004

Laurillard, D. (2002). Rethinking university teaching: A framework for the effective use of educational technology (2nd ed.). London, UK: Routledge.

Law, N. (2005). Assessing learning outcomes in CSCL settings. In T. Koshmann, D. Suthers, \& T-W Chan (Eds.), Computer Supported Collaborative Learning 2005: The next 10 years! (pp. 373-387). Mahwah, NJ: Erlbaum.

Lethinen, E., Hakkarainen, K., Lipponen, L., Rahikainen, M., \& Muukonen, H. (2001). Computer supported collaborative learning: A review (CL-Net Project). Retrieved from http://www.comlab.hut.fi/opetus/ 205/etatehtava1.pdf

Muilenburg, L. Y., \& Berge, Z. L. (2005). Student barriers to online learning: A factor analytic study. Distance Education, 26(1), 29-48. doi:10.1080/01587910500081269

Murphy, K. L., \& Cifuentes, L. (2001). Using web tools, collaborating, and learning online. Distance Education, 2, 285-305. doi:10.1080/ 0158791010220207

Northrup, P. T. (2001). A framework for designing interactivity into webbased instruction. Educational Technology, 41, 31-39.

Oksanen, K., \& Hämäläinen, R. (2012). Collaborative serious game as a sociable computer-supported collaborative learning environment. In P. Felicia (Ed.), Proceedings of the 6th European conference on game based learning (pp. 364-371). Reading, UK: Academic Publishing International.

Osterman, K. F. (2000). Students' need for belonging in the school community. Review of Educational Research, 70, 323-367. doi:10.2307/1170786

Palloff, R., \& Pratt, K. (2007). Building learning communities in cyberspace: Effective strategies for the virtual classroom ( $2 \mathrm{nd}$ ed.). San Francisco, CA: Jossey-Bass.

Pan, Y. C., Kuo, L., \& Lee, J. J. (2007). Sociability design guidelines for the online gaming community: Role play and reciprocity. In $\mathrm{D}$ Schuler (Ed.), Online communities and social computing (Lecture notes in computer science Vol. 4564; pp. 426-434). Berlin, Germany: Springer. doi:10.1007/978-3-540-73257-0_47

Preece, J (2000). Online communities: Designing usability, supporting sociability. New York, NY: Wiley.

Preece, J. (2001). Sociability and usability in online communities: Determining and measuring success. Behaviour \& Information Technology, 20, 347-356. doi:10.1080/01449290110084683
Rettie, R. (2005, September). Social presence as presentation of self. Paper presented at the 8th annual international workshop on Presence, London, UK.

Rourke, L., \& Anderson, T. (2002) Exploring social communication in asynchronous, text-based computer conferencing. Journal of Interactive Learning Research, 13, 259-275.

Rourke, L., Anderson, T., Garrison, D. R., \& Archer, W. (1999). Assessing social presence in asynchronous text-based computer conferencing. Journal of Distance Education, 14(3), 50-71.

Rovai, A. P. (2002). Sense of community, perceived cognitive learning, and persistence in asynchronous learning networks. The Internet and Higher Education, 5, 319-332. doi:10.1016/S1096-7516(02)00130-6

Scollins-Mantha, B. (2008). Cultivating social presence in the online learning classroom: A literature review with recommendations for practice. International Journal of Instructional Technology \& Distance Learning, 5(3). Retrieved from http://itdl.org/Journal/Mar_08/article02.htm

Selwyn, N. (2007, November 15). 'Screw Blackboard ... do it on Facebook!': An investigation of students' educational use of Facebook. Paper presented to the 'Poke 1.0 - Facebook social research symposium, University of London, UK.

Shea, V. (1997). Netiquette (online ed.) San Rafael, CA: Albion.com. Retrieved from http://www.albion.com/bookNetiquette/ 0963702513FC.html

Shen, K. N., Yu, A. Y., \& Khalifa, M. (2006). Supporting social interaction in virtual communities: Role of social presence. In Proceedings of the 12th Americas Conference on Information Systems (AMCIS) (pp. 4461-4469). AIS Electronic Library.

Short, J., Williams, E., \& Christie, B. (1976). The social psychology of telecommunications. London, UK: Wiley.

Smith, J. A. B. (2006). The effect of social presence on teacher technology acceptance, continuance intention, and performance in an online teacher professional development course (Unpublished doctoral dissertation). Orlando: University of Central Florida.

Spears, R., Postmes, T., Wolbert, A., Lea, M., \& Rogers, P. (2000). Social psychological influence of ICT on society and their policy implications [Electronic version]. Amsterdam, The Netherlands: Infodrome. Retrieved from http://infodrome.info/download/pdf/surv_spears.pdf

Sproull, L., \& Faraj, S. (1997). Atheism, sex, and databases: The net as a social technology. In S. Kiesler (Ed.), Culture of the internet (pp. 35-52). Mahwah, NJ: Erlbaum.

Stockdale, R., \& Thompson, K. (2008). The role of sociability in developing online health communities for people with diabetes. Health Care and Informatics Review Online, 12, 25-26.

Stodel, E. J., Thompson, T. L. \& MacDonald, C. J. (2006). Learners' perspectives on what is missing from online learning: interpretations through the community of inquiry framework. International Review of Research in Open and Distance Learning, 7, 1-24.

Strijbos, W. J., \& Laat, de, M. (2010). Developing the role concept for computer-supported collaborative learning: An explorative synthesis. Computers in Human Behavior, 26, 495-505. doi:10.1016/ j.chb.2009.08.014

Sveiby, K-E. (2001), A knowledge-based theory of the firm to guide in strategy formulation. Journal of Intellectual Capital, 2, 344-358. doi: $10.1108 / 14691930110409651$

Tu, C. H. (2000). On-line learning migration: From social learning theory to social presence theory in a CMC environment. Journal of Network and Computer Application, 23, 27-37. doi:10.1006/jnca.1999.0099

Tu, C. H. (2002). Critical examination of factors affecting interaction on CMC. Journal of Network and Computer Applications, 23, 39-58. doi:10.1006/jnca.1999.0100

Tu, C. H., \& McIsaac, M. (2002). The relationship of social presence and interaction in online classes. American Journal of Distance Education, 16, 131-150. doi:10.1207/S15389286AJDE1603_2

Tuckman, B. W., \& Jensen, M. A. (1977). Stages of small group development revisited. Group and Organizational Studies, 2, 419-427. 
Vanden Abeele, M., Roe, K., \& Pandelaere, M., (2007, October). Element validation of the concepts social presence, emotional presence and connectedness and an application of Zajonc's social facilitation theory to social presence research. Paper presented at the 10th annual international workshop on Presence, Barcelona, Spain.

Von Krogh, G., Nonaka, I. \& Ichijo, K. (2000). Enabling knowledge creation. New York, NY: Oxford University Press.

Voogt, J., \& Pelgrum, H. (2005). ICT and curriculum change. Human Technology: An Interdisciplinary Journal on Humans in ICT Environments, 1, $157-175$.

Vygotsky, L. (1978). Mind in society. Cambridge, MA: Harvard University Press.

Walker, B. K. (2007). Bridging the distance: How social interaction, presence, social presence, and sense of community influence student learning experiences in an online virtual environment (Unpublished doctoral dissertation). University of North Carolina at Greensboro.

Walther, J. B. (1993a). Impression development in computermediated interaction. Western-Journal of Communication, 57, 381-398. doi:10.1080/10570319309374463

Walther, J. B. (1993b). Validation of a quantitative measure of impression development. Southern Communication Journal. 59(1), 27-33. doi:10.1080/10417949309372919
Walther, J. B. (1996). Computer-mediated communication: Impersonal, inter-personal, and hyperpersonal interaction. Communication Research, 23, 3-43.

Wang, S., \& Noe, R. A. (2010). Knowledge sharing: A review and directions for future research. Human Resource Management Review, 20, 115131

Warketin, M. E., Sayeed, L., \& Hightower, R. (1997). Virtual teams versus face-to-face teams: An exploratory study of a web-based conference system. Decision Sciences, 28, 975-996.

Wegerif, R. (1998). The social dimension of asynchronous learning networks. The Journal of Asynchronous Learning Networks, 2(1), 34 49.

Whipp, J. L., \& Lorentz, R. A. (2009). Cognitive and social help giving in online teaching: An exploratory study. Education Technology Research and Development, 57, 169-192. doi:10.1007/s11423-008-91047

Wiley, D. (2006). Scalability and sociability in online learning environments. In H. F. O’Neil \& R. S. Perez (Eds.), Web-based learning: Theory, research, and practice (pp. 295-306). Mahwah, NJ: Erlbaum.

Yang, H. -H. (2007). The effect of technology acceptance on undergraduate students' usage of WebCT as a collaborative tool (Unpublished doctoral dissertation). University of Central Florida, Orlando. 